\title{
Metalation of 2-Phenylethyldimethylamine under Mild Conditions
}

\section{Key words}

lithium

benzylic metalation

potassium

Selected examples:<smiles>CN(C)CC(Br)c1ccccc1</smiles>

$92 \%$ yield
1. $t$-BuLi (1.7 equiv)

$t$-BuOK (1 equiv)

$\mathrm{Ph} \sim \mathrm{NMe}_{2}$

THF, -78 to $-60^{\circ} \mathrm{C}$

2. electrophile ( $\left.E^{+}\right)$(1 equiv)

$\mathrm{E}=\mathrm{Bu}, \mathrm{TMS}, \mathrm{SiMePh}_{2}, \mathrm{CPh}_{2} \mathrm{OH}, \mathrm{C}\left(\mathrm{C}_{5} \mathrm{H}_{10}\right) \mathrm{OH}$

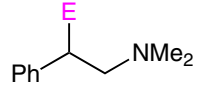

up to $92 \%$ yield
Significance: The direct benzylic metalation of 2 phenylethylamine derivatives suffers from $\beta$-elimination. The authors found that benzylic metalation of 2-phenylethyldimethylamine can be performed at $-78{ }^{\circ} \mathrm{C}$ with a mixture of $t$-BuLi and $t$-BuOK The metalated species was found to be stable up to $-40^{\circ} \mathrm{C}$.<smiles>Cc1ccc(C(CN(C)C)c2ccccc2)cc1</smiles>

$84 \%$ yield<smiles>Cc1ccccc1C(CN(C)C)c1ccccc1</smiles>

$60 \%$ yield<smiles>Cc1ccccc1CC(c1ccccc1)c1ccccc1</smiles>

$74 \%$ yield

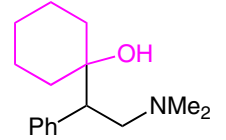

$84 \%$ yield
Comment: Interestingly, the metalation cannot be performed with a mixture of $t$-BuLi and $t$-BuOLi. Therefore, the potassium cation seems to be crucial for an efficient conversion. Theoretical and structural studies reveal that potassium is important for the lowering of the barrier of the initial deprotonation, as well as for stabilization of the labile anion. 